\title{
TRANSPLANTATION OF NEST OF AMAZONIAN TURTLE Podocnemis expansa (SCHWEIGGER, 1812)
}

\author{
TRANSPLANTE DE NINHOS DE TARTARUGA-DA-AMAZÔNIA Podocnemis Expansa \\ (SCHWEIGGER, 1812)
}

\author{
Thays Nogueira Lobo RIBEIRO'; ${ }^{\text {; Rodrigo Diana NAVARRO }}{ }^{1}$ \\ 1. Aquaculture and Biotechnology Laboratory in Aquatic Organisms, Faculty of Agronomy and Veterinary Medicine, University of \\ Brasília, Darcy Ribeiro University Campus, 70910-970, Brasília, Distrito Federal, Brazil. navarrounb@gmail.com
}

\begin{abstract}
The main objective of this study is to analyze the effectiveness of the Podocnemis expansa nest transplantation technique used to aid in the conservation of the species, aiming to increase the number of individuals in nature. The Amazonian turtle is famous for its large size and commercial attractiveness, being the target of rampant hunting, mainly by populations that depend on the species economically. In September 2018, natural nests of P. expansa that were in areas of flood risk were excavated and transplanted into new nests constructed by the team. At the same time, the breeding females had their dimensions verified, as well as their respective eggs. In the second stage of the experiment, which occurred in November of the same year, the nests previously transplanted were counted, including the amount of eggshell, indicating how many eggs hatched, and measuring the size of the newborns, besides the presence of deformities. The sand collected from the bottom and surface of the natural and transplanted nests were analyzed by sieving. Through Pearson's correlation, the data were tested and related. No significant relationships were found between the birth rate and the grain size of the nests, which shows that grain size did not influence the success of hatching in the present study. It was found a strong relation $(r=0.80)$ between the number of eggs and the percentage of deformities of each transplanted nest, showing that the presence of deformed individuals in turtle nests is natural.
\end{abstract}

KEYWORDS: Nidification. River. Testudines.

\section{INTRODUCTION}

The Amazon is the largest biome in the Brazilian territory, occupying around 4,196,943 $\mathrm{km}^{2}$ (IBGE, 2004). Within this area, it covers the famous Amazon Basin, recognized as the largest river basin in the world, containing a large number of tributary rivers. Due to its great extension, the Amazon displays a remarkable variety of niches, being able to shelter great diversity of living beings.

In Brazil, there are 36 of the 355 species of Testudines recognized by the world (VAN DIJK et al., 2014), comprising about $11 \%$ of the world fauna (MARTINS; SANO, 2004), most of which are present in the Brazilian Amazon (VAN DIJK et al., 2014). The Testudines are easily recognizable reptiles because they present a peculiar character and that is related to the evolutionary success of the group: the carapace. This highly differentiated apparatus is used to protect these animals since it consists of ossifications that cover the dorsal and ventral regions of the animal's body (POUGH et al., 2003). This group has already presented numerous populations, which resulted in great ecological influences exerted by the testudines, among them; they carry out the dispersion and promote the germination of seeds, act as soil bioturbators and miners of the marine soil, besides working in the cycling of nutrients and as consumers. (LOVICH et al., 2018)

One of the species of Testudines that can be found in Brazil is Podocnemis expansa, popularly known as Amazonian turtle or Arrau. This is considered one of the largest known freshwater turtle species, presenting an average size of $90 \mathrm{~cm}$ (LIMA, 1967) and weighing approximately $60 \mathrm{~kg}$ (SMITH, 1979). Its large size, a large number of eggs per spawning and its tasty meat made the species a target of unbridled hunting throughout the Amazon. (FACHÍN-TERÁN, 2001)

The individuals of Podocnemis expansa have climatic conditions as determining factors for their reproductive activity. Ferreira Jr. (2003) mentions that females of the species possibly check the temperature and humidity conditions of the beach before beginning spawning. While they are walking on the beach, they evaluate the conditions of sandy banks for nesting (VANZOLINI, 1967), being attracted by thinner sands with a low amount 
Transplantation of nest...

of gravel and free of vegetation (CASTRO; FERREIRA JÚNIOR, 2008).

The species is currently on the IUCN Red List in the low-risk and conservation-dependent category (IUCN, 1996), but with annotations that this data needs updating. According to MMA/Brazil (2010) and the Tortoise and Freshwater Turtle Specialist Group (2014) Podocnemis expansa, displays the status of Least Concern (LC). However, we don't have to wait for a species to become endangered to start caring about them. Within biodiversity conservation, each species has the right to exists and plays important roles in maintaining the balanced functioning of the ecosystem.

Thus, the need arose to create measures that promote the conservation of the species, presenting as main focus the protection of nests. The Amazonian Turtle has great importance for indigenous and riverine populations that often have them as a way to support their families, either through trade or for own consumption (CANTARELLI, 2006). Therefore, conservation measures also show respect for these populations, because when using certain conservation techniques, it is possible to increase the number of individuals of the species, enabling a sustainable trade. Soini (1997) cites a simple methodology for such an effect to be obtained: the nests' transplant technique, which consists of transferring nests from spawning beaches located in risky areas to more protected sites.

The transplant of nests of testudines is generally applied in areas where there was
RIBEIRO, T. N. L.; NAVARRO, R. D.

population reduction. The technique was introduced in Brazil in 1979, through the Amazonian Chelonians Program (PQA), in order to mitigate human predation and nests losses due to flooding in the spawning grounds (IBAMA, 1989). Using this method, in a conscious way and seeking to ensure the greatest possible similarity to natural nests, it is probable that there will be a population growth of the species and, consequently, the conservation of all the ecological interactions and services in which it is involved with. The objective of this study was to perform the transplantation of Podocnemis expansa nests on the Crixás-Açu River and evaluate its success, as well as its necessity.

\section{MATERIALS AND METHODS}

For the present study, an area with spawning history was chosen in the Crixás-Açu River, in the municipality of Mundo Novo in Goiás, Brazil. The research was divided into two stages: the first one occurred in September, in which 9 nests of Amazonian Turtle were evaluated, and the breeding females and their nests were identified, as well as their weighing and measurement. Afterward, the nests were opened, by hands, so that their respective eggs were counted, placed in plastic trays, as shown in Figure 1, and the egg transplantation started to the site of the new nests. Care was taken that the eggs were not exposed to the sun for a long time and that they were placed in the trays in the same position as they were in the nest.

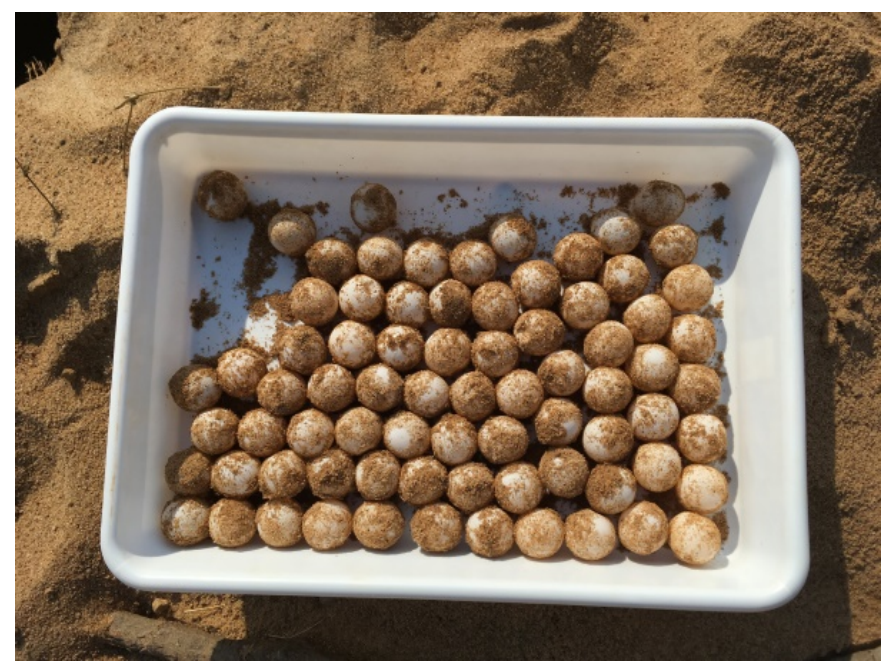

Figure 1. Eggs placed in a plastic tray. Source: photo of the authors

The artificial nests were excavated, also by hands (by hand), with depths and diameters close to those found in the natural ones. It is important to emphasize that the eggs were placed inside the new nests in the same position as in the natural nest
(IBAMA, 2016) and then each nest was identified with colored balls, as represented in Figure 2, and marked according to the breeder and identification number with a wood tag. 


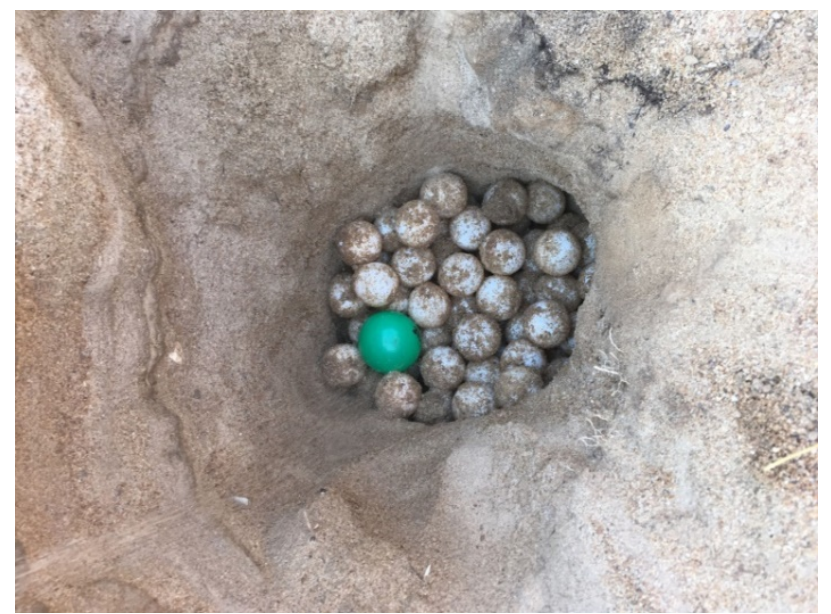

Figure 2. Nest identified with a colored ball. Source: photo of the authors

The second step, which took place in November, consisted of opening transplanted nests to evaluate the number of eggs hatched, through the number of eggshells, dead neonates and eggs. To calculate the hatching rate of eggs the following formula was used: number of hatching eggs X 100 / total number of eggs. The pups were measured with a digital caliper to measure the length and width of plastron and carapace, and weighed on a precision scale, in order to analyze possible deformities. In addition, oil eggs and eggshells were collected, and prey and forked nests were also identified. All these procedures were performed in the place so that there was no removal of any of the animals, neither injuries in any individual. After the procedures all neonates were released.

The nests were measured using a tape measure, measuring the depth and width, and from them, sand samples were collected from the bottom and surface of each nest to perform the granulometry procedure (CARNEIRO, 1983). During the construction of the transplanted nests, sediments were collected from the bottom and surface of each nest. Soil analysis was performed at the Soil Analysis Laboratories of the University of
Brasília (UnB). The degree of linear correlation and the direction of correlation between two variables were measured by the Pearson correlation index (CRESPO, 2002). The analyzes of the reproductive parameters of the Amazonian Turtle involving the mass in kilograms of the breeding females, the mass in grams of the eggs, the number of eggs per nest, deformity rate of each nest, hatching rate and percentage of fine sand were tested from the Pearson Correlation (r), performed from the program of Microsoft Excel 2010. The intensity of the correlations occurred as follows: $0<|\mathrm{r}|<0.40$ weak correlation, $0.40 \leq|\mathrm{r}|<0.7$ moderate and $0.70 \leq|\mathrm{r}| \leq 1$ strong correlation; following the proposal of Dancey and Reidy (2006).

\section{RESULTS}

One of the first steps of the project, carried out in September 2018, consisted in identifying the females and their respective nests, in addition to measuring the dimensions of both. The eggs were also counted and weighed. All these data can be observed in Table 1.

Table 1. Size and weight of the breeding stock; quantity and weight of eggs.

\begin{tabular}{ccccccc}
\hline $\begin{array}{c}\text { Nest } \\
\text { Number }\end{array}$ & $\begin{array}{c}\text { Weight } \\
\mathbf{( K g )}\end{array}$ & $\begin{array}{c}\text { Shell's length } \\
\mathbf{( c m )}\end{array}$ & $\begin{array}{c}\text { Shell's Width } \\
\mathbf{( c m )}\end{array}$ & $\begin{array}{c}\text { Shell's bending } \\
\mathbf{( c m )}\end{array}$ & $\begin{array}{c}\text { Amount of } \\
\text { eggs }\end{array}$ & $\begin{array}{c}\text { Average eggs' } \\
\text { weight (g) }\end{array}$ \\
\hline 1 & 27,55 & 67,0 & 51,5 & 70,0 & 95 & 40,27 \\
2 & 25,51 & 64,0 & 47,0 & 66,0 & - & 37,87 \\
3 & - & 65,0 & 46,0 & 66,0 & 76 & 34,67 \\
4 & 19,89 & 65,3 & 44,2 & 65,6 & - & 43,73 \\
5 & 24,86 & 66,0 & 47,0 & 70,0 & 85 & 41,53 \\
6 & 27,59 & 68,0 & 49,5 & 71,0 & - & 42,00
\end{tabular}


Transplantation of nest...

RIBEIRO, T. N. L.; NAVARRO, R. D.

$\begin{array}{lllllll}7 & 38,07 & 74,5 & 53,4 & 76,5 & 91 & 38,93 \\ 8 & 26,51 & 67,0 & 48,7 & 69,2 & - & 42,00 \\ 9 & 28,12 & 72,0 & 49,5 & 73,0 & 86 & 30,27\end{array}$

The parameter of the weight of the females was related to the weight of the eggs $(r=0.32)$ and the number of eggs $(r=0.34)$. However, none of the results was statistically significant, since $r<0.40$ was obtained. The analysis can be observed in Figures 3 and 4.
Carapace length and females' weight showed a strong correlation $(r=0,84)$, which can be observed in Figure 5.

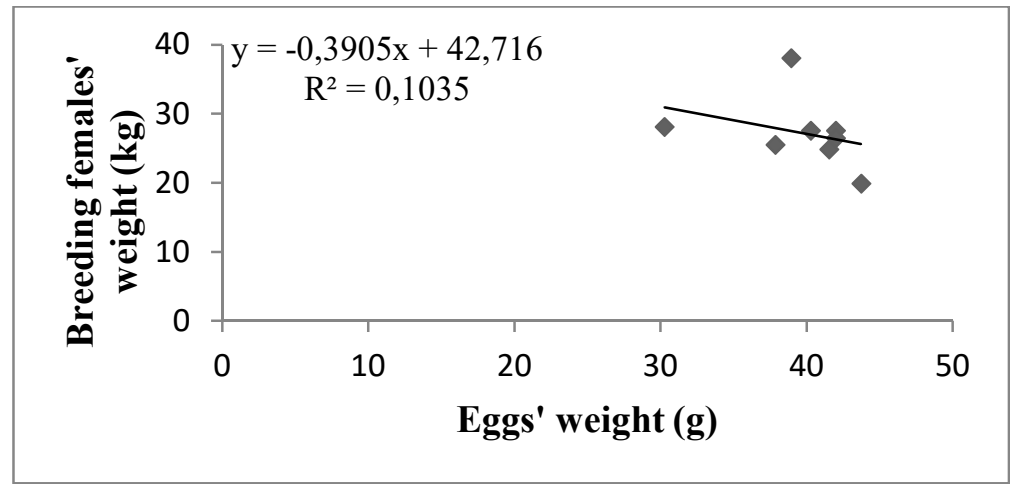

Figure 3. Correlation of the females' weight $(\mathrm{kg})$ with the average weight of their respective eggs $(\mathrm{g})$.

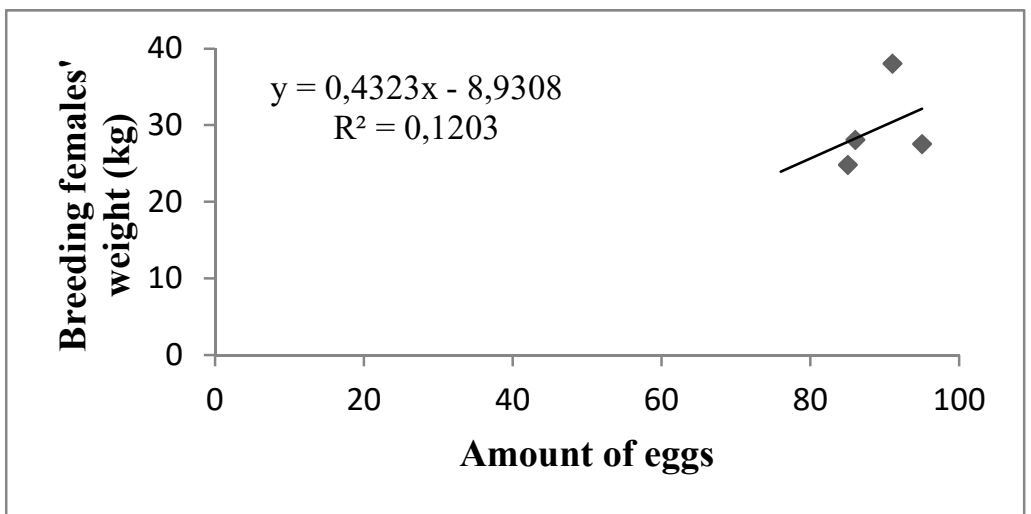

Figure 4. The weight of the breeding females of Podocnemis expansa related to the number of eggs of each nest represented by them.

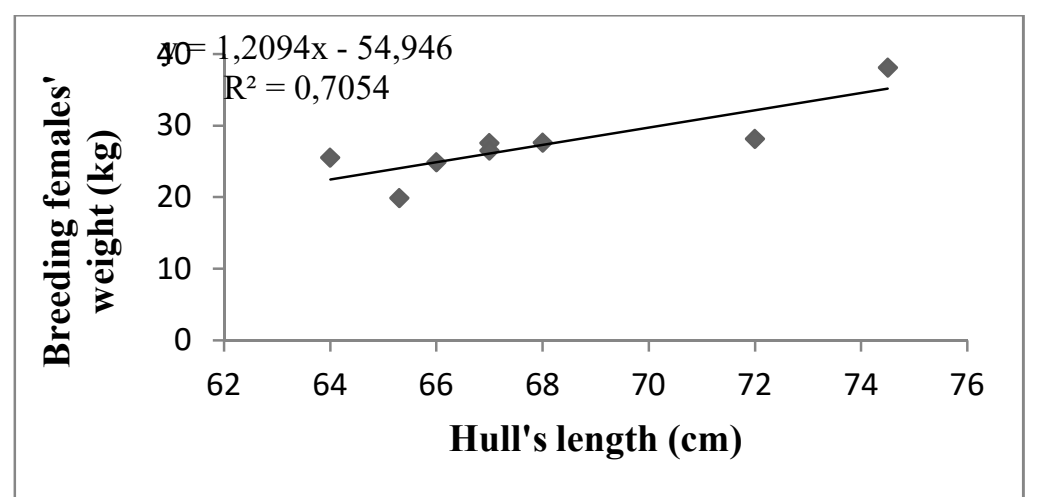

Figure 5. Correlation obtained between the mass of the breeding females $(\mathrm{kg})$ and the length of the hull $(\mathrm{cm})$. 
Transplantation of nest...

In order to achieve greater success with the nest transplantation technique and guarantee a hatching rate close to the natural, we must make the new nest with characteristics similar to the original ones. Thus, we built transplanted nests with
RIBEIRO, T. N. L.; NAVARRO, R. D.

measures similar to the initial nests, as can be seen by comparing Tables 2 and 3 .

After granulometric analysis of the collected material, through the sieving, the percentage of each plot was obtained according to grain sizes, that can be observed in Table 4.

Table 2. Dimensions of natural nests.

\begin{tabular}{ccc}
\hline $\begin{array}{c}\text { Natural nests } \\
\text { (id) }\end{array}$ & $\begin{array}{c}\text { Nest's depth } \\
\text { (cm) }\end{array}$ & Nest's width (cm) \\
\hline $\mathbf{1}$ & 70 & 30 \\
$\mathbf{2}$ & 65 & 25 \\
$\mathbf{3}$ & 50 & 39 \\
$\mathbf{4}$ & 60 & 30 \\
$\mathbf{5}$ & 65 & 40 \\
$\mathbf{6}$ & 60 & 30 \\
$\mathbf{7}$ & 60 & 30 \\
$\mathbf{8}$ & 60 & 35 \\
$\mathbf{9}$ & 60 & 18 \\
\hline
\end{tabular}

Table 3. Dimensions of transplanted nests.

\begin{tabular}{ccc}
\hline $\begin{array}{c}\text { Transplanted nests } \\
\text { (id) }\end{array}$ & $\begin{array}{c}\text { Nest's depth } \\
(\mathbf{c m})\end{array}$ & Nest's width (cm) \\
\hline $\mathbf{1}$ & 60 & 30 \\
$\mathbf{2}$ & 60 & 33 \\
$\mathbf{3}$ & 60 & 23 \\
$\mathbf{4}$ & 60 & 30 \\
$\mathbf{5}$ & 60 & 30 \\
$\mathbf{6}$ & 60 & 30 \\
$\mathbf{7}$ & 60 & 30 \\
$\mathbf{8}$ & 60 & 30 \\
$\mathbf{9}$ & 60 & 35 \\
\hline
\end{tabular}

Table 4. Percentage of granulometric plots of natural and transplanted nests (transp. nests).

\begin{tabular}{|c|c|c|c|c|c|}
\hline $\begin{array}{c}\text { Nests/Grains } \\
\text { (\%) }\end{array}$ & $G>2 \mathbf{m m}$ & $2 \mathrm{~mm}>\mathrm{G}>1 \mathrm{~mm}$ & $1 \mathrm{~mm}>\mathrm{G}>0,50 \mathrm{~mm}$ & $0,50 \mathrm{~mm}>G>0,25 \mathrm{~mm}$ & $\begin{array}{c}\mathbf{G}< \\
0,25 \mathrm{~mm}\end{array}$ \\
\hline Natural nest1 & 1,68 & 15,82 & 58,19 & 20,7 & 3,61 \\
\hline Natural nest2 & 0,67 & 9,92 & 59,72 & 25,15 & 4,37 \\
\hline Natural nest3 & 2,45 & 22,98 & 53,9 & 16,65 & 4,01 \\
\hline Natural nest4 & 2,28 & 15,1 & 50,68 & 25,62 & 6,26 \\
\hline Natural nest5 & 2,46 & 19,36 & 54,67 & 18,92 & 4,37 \\
\hline
\end{tabular}


Transplantation of nest...

RIBEIRO, T. N. L.; NAVARRO, R. D.

\begin{tabular}{lccccc} 
Natural nest6 & 2,08 & 12,45 & 54,31 & 29,19 & 1,88 \\
Natural nest7 & 2,46 & 17,81 & 58,77 & 16,85 & 3,96 \\
Natural nest8 & 1,28 & 15,09 & 62,94 & 18,07 & 2,77 \\
Natural nest9 & 1,51 & 14,23 & 61,68 & 19,72 & 2,81 \\
Trasnp. nest 1 & 1,97 & 20,65 & 62,91 & 11,17 & 3,26 \\
Trasnp. nest 2 & 2,19 & 28,8 & 47,41 & 12,32 & 6,41 \\
Trasnp. nest 3 & 2,29 & 20,57 & 58,32 & 12,04 & 6,41 \\
Trasnp. nest 4 & 2,39 & 22,5 & 55,63 & 13,42 & 5,93 \\
Trasnp. nest 5 & 1,77 & 15,2 & 48,46 & 23,6 & 10,9 \\
Trasnp. nest 6 & 2,22 & 15,43 & 45,57 & 15,22 & 21,26 \\
Trasnp. nest 7 & 4,75 & 31,86 & 54,02 & 7,5 & 1,8 \\
Trasnp. nest 8 & 2,57 & 29,94 & 60,14 & 5,52 & 1,83 \\
Trasnp. nest 9 & 7,48 & 34,3 & 49,74 & 7,34 & 1,04 \\
\hline
\end{tabular}

By calculating the averages of each granulometric plot of the natural and transplanted nests, it was possible to verify that the number of grains smaller than $0.25 \mathrm{~mm}$ was almost twice as large in the transplanted ones, as observed in Table 5 .

Table 5. Averages of the granulometric plots of the natural and transplanted nests.

\begin{tabular}{ccc}
\hline Grains (\%)/Nests & Naturals & Transplanted \\
\hline Grains $>\mathbf{2} \mathbf{m m}$ & 1,87 & 3,07 \\
$\mathbf{2} \mathbf{m m}>$ Grains $>\mathbf{1} \mathbf{m m}$ & 15,86 & 24,36 \\
$\mathbf{1} \mathbf{m m}>$ Grains $>\mathbf{0 , 5 0} \mathbf{m m}$ & 57,2 & 53,58 \\
$\mathbf{0 , 5 0} \mathbf{~} \mathbf{m} \mathbf{>}$ Grains $>\mathbf{0 , 2 5} \mathbf{m m}$ & 21,2 & 12,01 \\
Grains $<\mathbf{0 , 2 5} \mathbf{m m}$ & 3,78 & 6,54 \\
\hline
\end{tabular}

Therefore, as showed in Figure 6, a relationship between the hatching rate and percentage of grains less than $0.25 \mathrm{~mm}$ was sought.
However, the result was not significant, since it obtained $\mathrm{r}<0.40(\mathrm{r}=0.23)$.

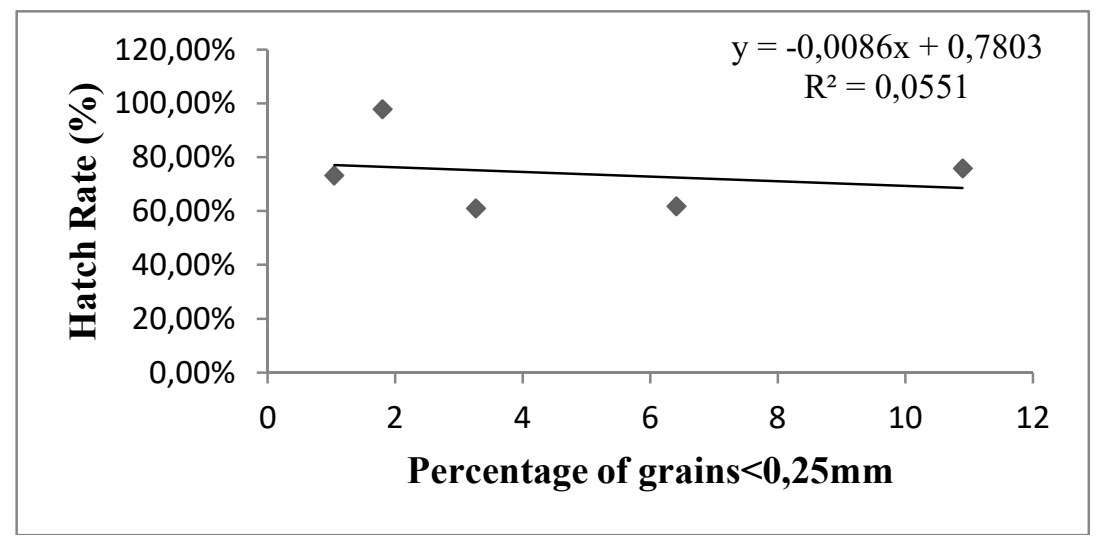

Figure 6. Hatch rate of the transplanted nests compared to the percentage of grains smaller than $0.25 \mathrm{~mm}$. 
Transplantation of nest...

In November 2018, in the opening stage of the transplanted nests, it was observed that nest 2 obtained all of its eggs aborted, while nest 8 was totally predated. Nests 4 and 6 were not found, probably due to the females themselves that passed through them carrying their identifications. In the rest of the nests, the neonates were weighed and had

\author{
RIBEIRO, T. N. L.; NAVARRO, R. D.
}

Table 6. Means of data from transplanted nests.

\begin{tabular}{cccccccc}
\hline $\begin{array}{c}\text { Transplanted } \\
\text { nests }\end{array}$ & Weight(g) & $\begin{array}{c}\text { Number Carapace's } \\
\text { of } \\
\text { shields }\end{array}$ & $\begin{array}{c}\text { length } \\
\text { (cm) }\end{array}$ & $\begin{array}{c}\text { Carapace'swidth } \\
\text { (cm) }\end{array}$ & $\begin{array}{c}\text { Plastron's } \\
\text { length } \\
\text { (cm) }\end{array}$ & $\begin{array}{c}\text { Plastron'swidth Deformities } \\
\text { (cm) }\end{array}$ & $\begin{array}{c}\text { (\%) } \\
\text { (cm }\end{array}$ \\
\hline $2 *$ & 27,58 & 23,84 & 5,48 & 5,15 & 4,64 & 2,54 & 52,63 \\
3 & - & - & - & - & - & - & - \\
$4_{*}^{*}$ & 26,28 & 23,7 & 5,32 & 5,12 & 4,6 & 2,45 & 10 \\
5 & - & - & - & - & - & - & - \\
$6_{*}^{*}$ & 22 & 23,89 & 5,18 & 4,44 & 4,36 & 2,87 & 0 \\
7 & - & - & - & - & - & - & - \\
$8^{*}$ & 26,95 & 23,95 & 5,25 & 4,92 & 4,47 & 2,53 & 37,5 \\
9 & - & - & - & - & - & - & - \\
\hline
\end{tabular}

From the percentage of deformed individuals in each nest, a comparison was made with the number of eggs of the respective nests, shown in Figure 7. The correlation obtained showed

$\mathrm{r}=0.80$; which indicates a strong relationship. An average hatch rate of $73.98 \%$ was found, ranging from $61.05 \%$ to $97.8 \%$, as represented in Table 7 .

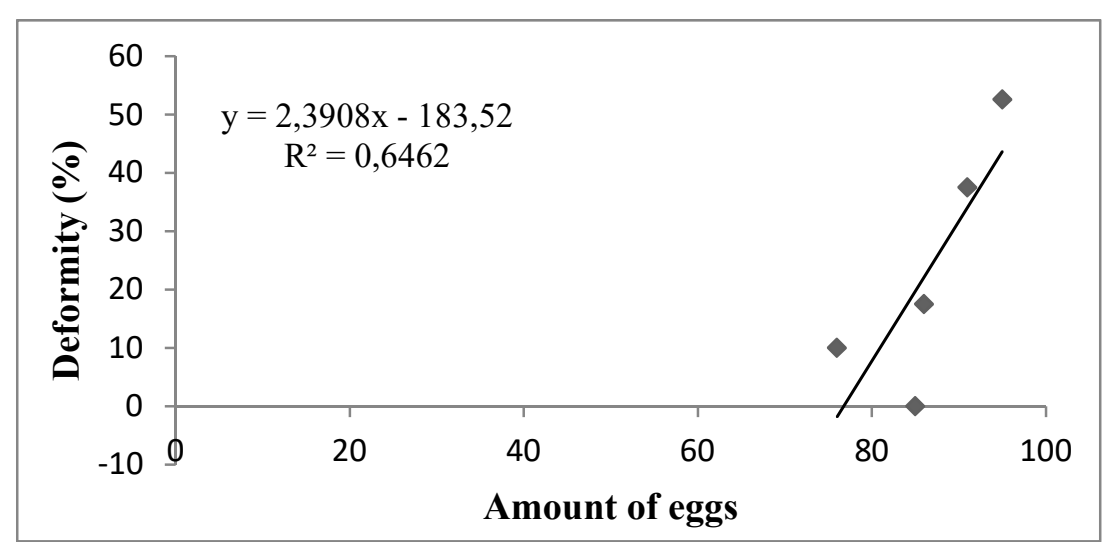

Figure 7. Percentage of deformed neonates compared to the number of eggs per nest.

Table 7. Hatch rate of transplanted nests compared to the natural nest hatch rate in the literature.

\begin{tabular}{ccc} 
Transplanted nests & Hatch Rate & Natural Hatch Rate \\
\hline 1 & $61,05 \%$ & \\
2 & - & $80 \%$ e $94,63 \%$
\end{tabular}




\section{Transplantation of nest...}

(PANTOJA-LIMA, 2008, ALVES-JÚNIOR et al.,2012)

\section{DISCUSSION}

The technique used in the present study led to the effective transplantation of about 55\% (5 nests) of the nests. In these nests an average hatching rate of $73.98 \%$ was observed, which is in agreement with Pantoja-Lima, 2008 where he observed an hatching rate of $80 \%$, another author such as Alves-Júnior et al., 2012 observed a hatching rate hatching of $94.63 \%$. The other nests that were not successful were $44 \%$, mainly due to predation and bony eggs, according to Jaffe et al. (2008) and Malvásio et al. (2005) observed that the egg transplantation technique has some disadvantages such as temperature and humidity variations to which the transplanted eggs are exposed, which could interfere in the formation of the embryo, and the rotation the eggs are submitted during their handling.

There was no significant difference between the sand granometry of transplanted nests and natural nests in relation to hatching rate. As the nest transplant site occurred on the same beach, the sand granolometry did not vary. Turtles of the Amazon region have a preference for sands of finer granulometry for the production of their nests because the size of the sediment influences the success of hatching, the duration of incubation and the spawning period (FERREIRA-JÚNIOR; CASTRO, 2010). Ferreira-Júnior and Castro (2010) observed that in nests of $P$. expansa an inverse relationship exists between sediment size and hatching success, that is, the larger the grain, the lower the success.

Among the nests found that had their eggs hatched, most presented deformation in the neonates. According to the dissertation of Pantoja Lima (2007), it is natural the birth of individuals deformed in turtle nests, becoming even more pronounced when the litter exceeds 100 eggs. It is possible to observe in Figure 5 of this study a positive relationship between the percentage of newborns and the number of eggs. Also the temperature may have the potential to affect the hatchlings development (YNTEMA, 1960). Another studies (LYNN; ULRICH, 1950; WIESNER; IBEN, 2003) showed that alterations in moisture levels may produce abnormal hatchlings.

The main importance of the nest transplant technique is to increase the number of individuals of the species, preventing death by flooding and predation of the eggs. However, despite decreasing egg loss, it does not prevent predation after hatching. Soon, at birth, the pups of $P$. expansa are exposed to the risk of being hunted by several predators during their walk to the water. So, is it worth saving individuals through transplant if they will be upon birth? Ojasti $(1967$; 1971) states that the mortality of newly hatched neonates of $\mathrm{P}$. expansa is approximately $5,9 \%$. Comparing this loss with the mortality generated by the flood of nests, it is worth performing the transplant process. In the case of freshwater turtles, river floods are one of the main causes of nests loss, because they spawn close to the river banks (FERREIRA JR., 2009). Alho and Pádua (1982) point out that $99 \%$ of Amazonian tortoise nests were lost due to the elevation of the Trombetas River in Pará.

For the purpose of perform the nest transplantation technique, in order to mitigate the losses caused by sudden changes in the level of the river, the nests located in lower and closer to the river areas, are identified. Then, to avoid nest losses, they are transplanted to higher areas in the same region, to interfere as little as possible in the reproductive cycle (IBAMA, 2016). Therefore, this technique can be easily applied and may reduce the impacts of flash floods.

\section{CONCLUSION}

With the results obtained in this work, we conclude that the transplantation of nests is an important tool to save nests exposed to flood risks, however there is a need for further studies to improve the technique. In addition, it should not be used in all situations because it leads to interference, even if minimal, in the animals' reproductive cycle. 
Transplantation of nest...

\section{ACKNOWLEDGMENT}

We would like to thank IBAMA of GoianiaGO for the partnership and logistical support, the
RIBEIRO, T. N. L.; NAVARRO, R. D.

research team of the Acqua UnB laboratory of the University of Brasília and all the students who contributed to the completion of the work.

RESUMO: Esse estudo teve como principal objetivo analisar a eficácia da técnica de transplante de ninhos de Podocnemis expansa para ajudar na conservação da espécie, buscando aumentar a quantidade de indivíduos na natureza. A tartaruga-da-Amazônia é famosa pelo seu grande tamanho e sua atratividade comercial, sendo alvo da caça desenfreada, principalmente por populações que dependem da espécie economicamente. Em setembro de 2018, ninhos naturais de $P$. expansa que se encontravam em áreas de risco de alagamento foram escavados e transplantados em novos ninhos construídos pela equipe. Nessa mesma época, as fêmeas reprodutoras tiveram suas dimensões aferidas, bem como a de seus respectivos ovos. $\mathrm{Na}$ segunda etapa do experimento, que ocorreu em novembro do mesmo ano, foram observados os ninhos que haviam sido transplantados anteriormente, contando-se a quantidade de casca, que indica quantos ovos eclodiram, e medindo as dimensões dos neonatos, além da presença de deformidades nos mesmos. Areias coletadas do fundo e da superfície dos ninhos naturais e dos transplantados foram analisadas através da peneiração. Através da Correlação de Pearson, os dados foram testados e relacionados. Não foram encontradas relações significativas entre a taxa de eclosão e a granulometria dos ninhos, o que mostra que o tamanho dos grãos não influenciou no sucesso da eclosão neste estudo. Constatou-se uma forte relação $(r=0,80)$ entre a quantidade de ovos e a porcentagem de deformidades de cada ninho transplantado, mostrando que é natural a presença de indivíduos deformados em ninhos de tartaruga.

PALAVRAS-CHAVE: Nidificação. Testudines. Rio.

\section{REFERENCES}

ALHO, C. J. R.; PÁDUA, L. F. M. Sincronia entre o regime de vazante do rio e o comportamento de nidificação da tartaruga da Amazônia Podocnemis expansa (Testudinata: Pelomedusidae). Acta Amazonica, v. 12, n. 2, p. 323-326, 1982. Disponível em: <https://www.scielo.br/scielo.php?pid=S004459671982000200323\&script=sci_arttext $>$. Acesso em: 10 jan. 2019.

ALVES-JÚNIOR, J. R. F.; LUSTOSA, A. P. G.; BOSSO, A. C. S.; BALESTRA, R. A. M.; BASTOS, L. F.; MIRANDA, L. B. AND SANTOS, A. L. Q. Reproductive indices in natural nests of giant Amazon river turtles Podocnemis expansa (Schweigger, 1812) (Testudiness, Podocnemididae) in the Environmental Protection Area Meanders of the Araguaia river. Brazilian Journal of Biology, v. 72, n. 1, p. 199-203, 2012. Disponível em: $<$ https://www.scielo.br/scielo.php?pid=S1519-69842012000100024\&script=sci_arttext $>$. Acesso em: 07 jan. 2019.

CANTARELLI, V. H. Alometria Reprodutiva de Tartaruga-da-Amazônia (Podocnemis expansa): bases biológicas para manejo. São Paulo: Universidade de São Paulo, 2006. Dissertação de doutorado. Disponível em: < https://www.teses.usp.br/teses/disponiveis/91/91131/tde-16102006-163143/en.php>. Acesso em: 09 jan. 2019.

CARNEIRO, C. C. Influência do ambiente de nidificação sobre taxa de eclosão, duração da incubação e a determinação sexual em Podocnemis (Reptilia, Podocnemididae) no Tabuleiro do Embaubal Rio Xingú. Belém: Universidade Federal do Pará, 2012. Dissertação de Mestrado. Disponível em: <http://200.239.66.58/jspui/handle/2011/6025>. Acesso em: 09 jan. 2019.

CASTRO, P. T. A.; FERREIRA JÚNIOR, P. D. Caracterização ecogeomorfológica das áreas de desova de testudines de água doce (gênero Podocnemis) no entorno da ilha do bananal, rio Araguaia. Geografias, v. 4, n. 1, p. 15-22, 2018. Disponível em: <http://www.repositorio.ufop.br/handle/123456789/4612>. Acesso em: $22 \mathrm{de}$ abr. 2019. 
FACHÍN-TERÁN, A. Situação da tartaruga-da-amazônia Podocnemis expansa na Reserva de Desenvolvimento Sustentável Mamirauá, Amazonas, Brasil. Reunião Especial da SBPC, v. 7, 2001.

FERREIRA JR., P. D. Influência dos processos sedimentológicos e geomorfológicos na escolha das áreas de nidificação de Podocnemis expansa (tartaruga-da-amazônia) e Podocnemis unifilis (tracajá), na bacia do rio Araguaia. Ouro Preto: Universidade Federal de Ouro Preto, 2003. Dissertação de doutorado.

FERREIRA JR., P.D. Efeitos de Fatores Ambientais na Reprodução de Tartarugas. Acta Amazônica, v. 39, n. 2 , p. 319-334, 2009. Disponível em: $<$ https://www.scielo.br/scielo.php?pid=S004459672009000200011\&script=sci_arttext>. Acesso em: 15 abr. 2019.

FERREIRA JR., P. D.; CASTRO, PTA. Nesting ecology of Podocnemis expansa (Schweigger, 1812) and Podocnemis unifilis (Troschel, 1848) (Testudines, Podocnemididae) in the Javaés River, Brazil. Brazilian Journal of Biology, v. 70, n. 1, p. 85-94, 2010. Disponível em: < https://www.scielo.br/scielo.php?pid=S151969842010000100012\&script $=$ sci_arttext $>$. Acesso em: 14 abr. 2019.

GAFFNEY, E. S., P. A. MEYLAN, AND A. R. WYSS. A computer-assisted analysis of the relationships of the higher categories of turtles. Cladistics, v. 7, n.4, p. 313-335, 1991. Disponível em: < https://onlinelibrary.wiley.com/doi/abs/10.1111/j.1096-0031.1991.tb00041.x>. Acesso em: 25 abr. 2019.

INSTITUTO BRASILEIRO DO MEIO AMBIENTE E DOS RECURSOS NATURAIS RENOVÁVEIS, IBAMA. Projeto Quelônios da Amazônia: Manual Técnico. IBAMA: Brasília, p. $125,1989$.

INSTITUTO BRASILEIRO DO MEIO AMBIENTE E DOS RECURSOS NATURAIS RENOVÁVEIS, IBAMA. Manejo conservacionista e monitoramento populacional de quelônios amazônicos. IBAMA: Brasília, p. 15-28, 2016. Disponível em: < https://www.researchgate.net/profile/Camila_Kurzmann_Fagundes/publication/313110568_Manejo_ Conservacionista_e_Monitoramento_populacional_de_Quelonios_Amazonicos/links/589099a9aca272 bc14be6526/Manejo-Conservacionista-e-Monitoramento-populacional-de-Quelonios-

Amazonicos.pdf\#page=16 >. Acesso em: 30 abr. 2019

INTERNATIONAL UNION FOR CONSERVATION OF NATURE et al. IUCN red list of threatened animals. International Union for Conservation of Nature and Natural Resources, 1996.

JAFFÉ, R., PEÑALOZA, C., BARRETO, G. R. Monitoring an endangered freshwater turtle management program: effects of nest relocation on growth and locomotive performance of the giant south american turtle (Podocnemis expansa, Podocnemididae). Chelonian Conservation and Biology, v. 7, n. 2, p. 213-222, 2008. Disponível em: < https://meridian.allenpress.com/ccb/article-abstract/7/2/213/26812>. Acesso em: 20 mar. 2019.

LIMA, F. F. Criação de peixes e quelônios: cria e recria em lago natural. Secretaria de Produção, 1967.

LOVICH, J. E., ENNEN, J. R., AGHA, M. and GIBBONS, J. W. Where Have All the Turtles Gone, and Why Does It Matter? BioScience, v. 68, n. 10, p. 771-781, 2018. Disponível em: $<$ https://academic.oup.com/bioscience/article/68/10/771/5079873>. Acesso em: 15 mai. 2019

LYNN, W. G.; ULlRICH, M. C. Experimental Production of Shell Abnormalities in Turtles. Copeia, v. $4 \mathrm{n}$ 253, 1950. Disponível em: <https://www.jstor.org/stable/1437903>. Acesso em: 15 mai. 2019. 
MALVASIO, A. et al. Análise da interferência do manuseio dos ovos no índice de eclosão e no padrão de escutelação do casco e as correlações encontradas entre as medidas das covas, ovos e filhotes em Podocnemis expansa (Schweigger, 1812) e P. unifilis (Troschel, 1848) (Testudines, Podocnemididae). Publicações avulsas do Instituto Pau Brasil de História Natural, v. 8, n. 10, 2005. Disponível em: < https://biblat.unam.mx/en/revista/publicacoes-avulsas-do-instituto-pau-brasil-de-historianatural/articulo/analise-da-interperencia-do-manuseio-dos-ovos-no-indice-de-eclosao-e-no-padrao-deescutelacao-do-casco-e-as-correlacoes-encontradas-entre-as-medidas-das-covas-ovos-e-filhotes-empodocnemis-expansa-schweigger-1812-e-p-unifilis-troschel-1848-testudines-pelomedudidae>. Acesso em: 20 mai. 2019.

MARTINS, M. H. B.; SANO P. T. Biodiversidade tropical. São Paulo: Editora Unesp, 2004.

OJASTI, J. Consideraciones sobre la ecologia y conservación de la tortuga Podocnemis expansa (Testudines, Pelomedusidae). Atas Simpósio Biota Amazônica, v. 7, p. 201-206, 1967.

OJASTI, J. La tortuga arrau del Orinoco. Defensa de la Natureleza, v.1, n. 2, p. 3-9, 1971.

PANTOJA-LIMA, J., Aspectos da ecologia reprodutiva de Podocnemis expansa, Podocnemis sextuberculata e Podocnemis unifilis (Testudiness, Podocnemididae) na Reserva Biológica do Abufari, Amazonas, Brasil. Amazonas: Universidade Federal do Amazonas, 2007. Dissertação de mestrado.

POUGH, F. H.; JANIS, C. H.; HEISER, J. B. A vida dos vertebrados. 3. ed, São Paulo: Atheneu, 2003.

SMITH, N. J. H. Quelônios aquáticos da Amazônia: um recurso ameaçado. Acta Amazonica, v. 9, n 1, p. $87-$ 97, 1979. Disponível em: <https://www.scielo.br/scielo.php?pid=S004459671979000100087\&script=sci_arttext>. Acesso em: 22 abr. 2019.

SOINI, P. Ecología y manejo de quelonios acuáticos en la amazonía peruana. Manejo de Fauna Silvestre en la Amazonía, p. 167-173, 1997.

VAN DIJK, P. P. V.; IVERSON, J. B.; RHODIN, A.G. J.; SHAFFER, H. B.; BOUR, R. Turtles of the World, 7th Ed. Annotated checklist of taxonomy, synonymy, distribution with maps, and conservation status. Testudines Research Monographs, v. 5, p. 329-479, 2014

VANZOLINI, P. E. Notes on the nesting behavior of Podocnemis expansa in the Amazon Valley (Testudines: Pelomedusidae). Papéis Avulsos Zoologia, v. 20, p.191-215, 1967.

VOGT, Richard Carl. Tartarugas da Amazônia. INPA-Instituto Nacional de Pesquisas da Amazônia, 2008.

WIESNER, C. S.; IBEN, C. Influence of environmental humidity and dietary protein on pyramidal growth of carapaces in African spurred tortoises (Geochelone sulcata). Journal of Animal Physiology and Animal Nutrition, v. 87 n 1-2, p. 66-74. Disponível em: <https://onlinelibrary.wiley.com/doi/abs/10.1046/j.14390396.2003.00411.x>. Acesso em: 15 mai. 2019. 